\title{
Social Business in the Logic of Capitalism Rhizomatic: Alternative of Resistance or Trademark Modeling?
}

\author{
Giselle Gama Torres Ferreira*, Fred Tavares, Jefferson Fernando, Eliane Monteiro de Almeida \\ Eicos Program (Psychos Sociology of Communities and Social Ecology, Institute of Psychology), Federal University of Rio de Ja- \\ neiro (UFRJ), Rio de Janeiro, Brazil \\ Email: *giselletorres.com@gmail.com, frederico.tavares@eco.ufrj.br, oojefferson@gmail.com, elianealmeida@ufrj.br
}

How to cite this paper: Ferreira, G.G.T., Tavares, F., Fernando, J. and de Almeida, E.M. (2018) Social Business in the Logic of Capitalism Rhizomatic: Alternative of Resistance or Trademark Modeling? Open Journal of Social Sciences, 6, 318-332. https://doi.org/10.4236/jss.2018.69022

Received: July 31, 2018

Accepted: September 27, 2018

Published: September 30, 2018

Copyright (c) 2018 by authors and Scientific Research Publishing Inc. This work is licensed under the Creative Commons Attribution International License (CC BY 4.0).

http://creativecommons.org/licenses/by/4.0/

\begin{abstract}
Significant changes in the social, political, economic and environmental structures that affect the individual and the environment that surrounds him are observed in contemporary times. In this new logic, alternatives emerge from business models that act directly on social tensions and may or may not impact the individual and the environment that surrounds them. In this context, a new concept of management called social business arises, which seeks to develop market solutions that can contribute to reduce the inherent consequences of social and environmental problems. In this kind of business proposal, profit is not an end in itself but a means to generate solutions that help reduce poverty, social inequality and environmental degradation. However, the consumer society, which has as its backdrop Rhizomatic Capitalism, reveals that the issues inherent in nature and the social problematic can be appropriated as a strategic tool to feed the marketing logic in favor of capital. Therefore, the purpose of this paper is to analyze whether or not the social business management in less affluent communities in the context of the consumer society aligns with the proposal of overcoming environmental and social problems from the discussion of authors such as Deleuze, Guattari and others who with these dialogues. It is questioned whether the development of social business can be observed from the perspective of Rhizomatic Capitalism, which adapts itself to incite new brand models produced and reproduced in the market, multiplying subjectivities even more rooted in consumption and profit. Therefore, this research discusses, from a clipping, a look at the social business creation movement in Brazil. The methodology adopted is qualitative, bibliographical and documentary exploratory research. From the theoretical framework constructed, campaigns, social media and reports from the Moradigna startup are analyzed. The idea is to build a look at this movement from a case study carried out through the application of the Content
\end{abstract}


Analysis method inspired by the precepts of Bardin. It is identified, through this study, a possible applicability of projects installed under the social business model as well as the aspect that assumes in the context of the Consumer Society. From this crop, this research aims to analyze and identify some clues about the potential and consistency of Social Affairs as alternative business models and of resistance to the logic of profit or as mere movement of reproduction of the consumer models installed contemporaneity.

\section{Keywords}

Trademark Modeling, Social Business, Rhizomatic Capitalism, Society of Control

\section{Introduction}

The interest in issues inherent to sustainability, social issues, permeates several fields of knowledge and market sectors in contemporaneity. This is because the advancement of technology development, in parallel to the growing limitation of natural resources available, in the late 20th century, resulted in major adverse impacts on social and business scenarios in most markets in the world. The socio-environmental issue, in sight of it, integrates the business discussion guidelines and governmental [1] and the need for development of new business models becomes one of the key topics in the context of contemporaneity.

The imminent need to develop new values and socio-economic models aimed at reducing social and environmental impacts has led to the emergence of new business models that are becoming present in different segments of the market and society. In this context, emerges a new type of organization, which combines two previously seen as incompatible goals: financial sustainability and social value [2].

Social and environmental imbalances are factors that have boosted the social business. This is a subject that has aroused the attention of researchers and executives in the world and in Brazil [3].

According to Tavares and Ferreira [4], "[...] by mid-1980 and 1990, speak on responsible consumption was understood as something unimportant. Ecological products and services and socially correct were too difficult to find In the 2000s, so-called social businesses began to emerge and become reference as business models aimed at generating impact on society and improving the world. However, many companies also take ownership of the social and environmental issues to associate their products and services to the argument of the "promotion of social impact" and, therefore, engage profits.

Despite the growing interest in the subject, there is still much skepticism in relation to impact business. After all, as associate financial return and social impact, two elements historically seen as antagonistic? Even in the more traditional concept proposed by Yunus, the impact businesses seek financial results so that the organization can be self-sustaining [5]. 
However, there is a collective consensus that natural resources are increasingly depleted, and that we live on a planet of finite resources. In this way, social businesses emerge to join efforts in the same direction, focusing on less waste and higher income. However, this requires sustainable innovation systems that help reduce scheduled obsolescence, and improve processes that aim to reduce social costs, and therefore lower costs to final consumers.

According to Almeida [6]:

The prerequisites for success have, from now on, another environment to be considered, which includes factors such as health of a community or the planet, a life-support system-human or otherwise-of an environment, considering a deep understanding of social consequences and other factors that were not regularly considered mandatory.

In this vein, the Brazilian corporations, inserted into a fluid and complex psychosocial context, are concentrating their efforts on business actions that expose and ratify the business engagement with social impact. And, if you associate with social and ecological issues, seek to add value to your business by building the credibility factor among the stakeholders ${ }^{1}$ [7].

According to Almeida [6], this new way of working is not an incremental innovation, but it is a profound structural change with a long-term perspective, aimed at practicing what every global community recognizes as sustainable development in three dimensions: social, environmental and economic development. In this way, in his book Almeida [6] proposes as an improvement of processes to structure sustainable innovation, the FSSD (Framework for Strategic Sustainable Development, Blekinge Institute of Technology, 2008) methodology, which was developed and has been improved along with business leaders, universities, environmentalists, communities that involve workers, teachers and various social actors. If the FSSD is used in business planning, the results will appear positively in a win-win model. Above all, sustainable innovation fosters new ways of being sustainable and is aligned with the vision of Sustainable Development Objectives (SDO) ${ }^{2}$, illustrated in Figure 1.

In view of the need to discuss new forms of business in Postmodernity, the general objective of this study is to investigate how the socio-environmental problems might be appropriate in the Constitution entitled business such as strategic tool to feed and reproduce the market for the benefit of capital logic. The specific objective of this study is to understand if the social business model represents an alternative form of resistance, namely, assess their potential and consistency of social business models of alternative business facing the logic of profit. Therefore, this research aims to promote a study on the correlation of the creation of social business in synergy to the formation of a critical reflection

${ }^{1}$ Any actors who have interests and expectations of the Organization, i.e. shareholders, employees, contractors, suppliers, consumers, clients, community, Government, society.

${ }^{2}$ The Sustainable Development Goals (SDG) were finalized in 2015 at the United Nations Summit on Sustainable Development. The process initiated in 2013, following a mandate emanating from the Rio + 20 Conference, the SDG should guide national policies and international cooperation activities in the next fifteen years, succeeding and updating the Millennium Development Goals (MD). 


\section{(6) OBJETIVE"'sS DE DEEENOLVIMENTO}
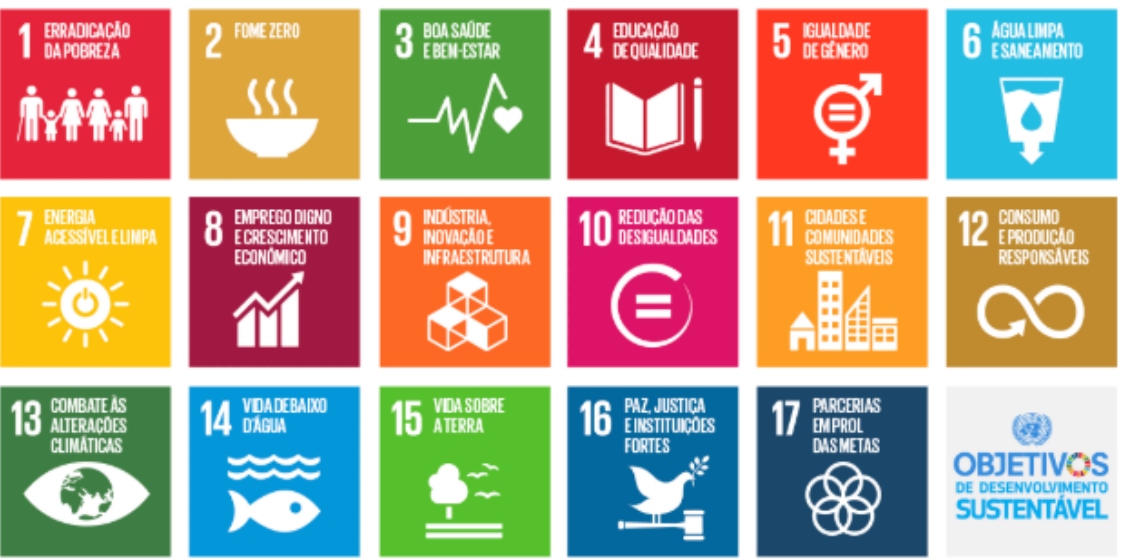

(93)

OBJETIVOS

DE DESENVOLYMENTO

Figure 1. Sustainable Development Objectives (SDO). Source: Foreign Office website (BRAZIL, 2018).

about the central idea "make money and change the world" [8].

The ownership of the research object aims, therefore, exemplify and discuss it-from a clipping built from the theoretical that follows the trail of Deleuze and Guattari-how social business models manifest themselves in Brazil, and if your implicit objectives consistent with the original purpose of creating value for society. It is the proliferation of new business models that seek to generate social impact, in a psychosocial approach, which highlights the relevance to the interest in exploring this market and social process.

In this context, the justification for such a study is unveiling the use of social and environmental problems as a way of creating arguments that are in synergy with the emergence of a kind of trademark social modeling or as a form of socialwashing/publiwashing. The study discusses the actions of business models with respect to speech "improve the world" but that, in essence, aimed at other purposes that are not primarily involved with social and environmental issues. The possible incompatibility of the use of the subject matter in a society whose consumption is ephemeral and fleeting is questioned, and in which the political role of brands is to encourage an excessive compulsion for "having", more and better [9].

The fundamental questioning of this paper is: the social businesses created in Brazil have the same motivation or the same purpose? The actions understood how "sustainable" promoted by this business model serves to further stimulate the consumption or promote the reflection? In addition, the study becomes relevant in your new function, in that it proposes to carry out a theoretical framework still little developed in Brazil.

The methodology used is the exploratory research made by means of a qualitative study of reports about the startup Moradigna, collected from digital collection. To understand how is the movement of social business creation, the study 
is based on a case study drawn from the theoretical foundation built through the bibliographic and documentary research. The data analysis is based on content analysis technique, from the precepts of Bardin [10].

Through the application of the methodology chosen, the expected result is the construction of a questioning starting from a critical eye-reflective of the psychosocial problems linked to the proliferation of Social business just as trademark modeling. How is constructed and feedback to the process of creating new business models with socio-environmental appeal from the perspective of Rhizomatic Capitalism? The study focuses on the hypothesis that social businesses have appropriate social and environmental argument in order to stimulate a continuous and incessant flow of consumption and profitability of the individual in instead of promoting the social impact that predisposes in the first moment. Seeing this, inquires: What's the backdrop that serves as a backdrop for the emergence of social business in contemporary times?

\section{IWC to Rhizomatic Capitalism: The Rooting of Life from/to Consumption}

To understand how the process management of business models under the logic of consumption, it is necessary to understand how capitalism has been re-signified to survive as profitable production system in a reality of intensive transformations. In this new logic, the capital is involved with the production of new subjectivities, with the immateriality and intangibility, new identities that underpin the consumption cycle entangled by desire [11]. Second Sibilia [12] and Alliez [13], these new subjectivities are premised, pursuing the logic of Integrated World Capitalism-IWC_-[14] that unfolds in a Rhizomatic Capitalism [15].

According to Guattari, capitalism [14] to maintain, operate in more complex and different devices of power-know. The dynamics of capital is going network and virtually, pursuing the idea of maximum connection. Thus, the IWC working so that the sectors indirectly connected to the production machine become supporting players to the productive sector and which also produce means of contributing to the logic of consumption. According to Camargo [16]:

Subjectivity capitalized, produced by collective equipment has the function to make homogeneous the values of capitalism, preparing individuals for economic production and subjective. Even if an individual, who went by the collective equipment's, can't be inserted into the world of work to produce, he'll be able to make subjective relations capitalized [16].

The phenomenon of consumption, on the model of the IWC shall be from Rhizomatic Capitalism [15], which commercialises the desire and produces new subjects who live in under the mobile society, plural logic and ephemeral and desterritorialized. In view of this capitalism, which unfolds in a Rhizome, there's the deconstruction of the self, which makes room for the penetration of an intangible, fluid, global capitalism and connectionist [15]. 
Pelbart [15], in your book Life Capital, talks about what would Rhizomatic Capitalism raising questions such as why capitalism "get" same setting as a system that reaffirms and extends the exclusion and the social inequalities. What are the mechanisms of adhesion used by him? That justification capitalism gives your stay? As he disarms his critics? According to the author, from the years of 1980, capitalism has incorporated many criticisms levelled at him in the 1960 and 1970, reinventing and redesigning itself to resist the hard process of loss of credibility for what was experiencing. On that logic, capitalism passes the appropriate elements as: autonomy, freedom, gain credibility, and if so within a network called by the author of Rhizome, marked by fluidity. Pelbart [15] comments on this new formatting of capitalism:

Means to satisfy in part these libertarian claims, autonomists, hedonists, imaginative, existential capitalism might at the same time mobilize in their workers before unattainable spheres [15].

For Pelbart [15], this new setting is in this "commodified" Rhizome of capital (open, flexible and connectionist), the essential conditions for creating mutations within the market. Is this Rhizomatic Capitalism, light, fluid, global and extra-territorial consumption, through the logic of desire-which is becoming, is installed. In this perspective, the goods and services are rewritten to model and meet the demands of the needs-desires produced by the market. From this logic, this "network" reconfigured through a Rhizome, through which all affect and are influenced through mutual arrangements. Pelbart complements:

The connectionist world is entirely Rhizomatic, not a finalist, not identity, favors the hybrids, migration, multiple metamorphoses interfaces, etc. Of course, the ultimate goal of capitalism remains the same, aims to profit, but the way in which he now tends to accomplish it, and this is the authors

'thesis is primarily through the network [15].

From Pelbart perspective [15], the Rhizomatic Capitalism pursues the profit, working with more complex logic of production, creating new needs "ways of being" [17], new identities, new demands, new strategies. In the logic of Rhizomatic Capitalism, as already seen, it is necessary to consume and buy, always more and better, however in order to encourage more and more wishes transmuted in need.

Thus, the postmodern society brings a kind of consumption "password" of belonging, to be "inside", "part" of the extra-territorial space of Rhizomatic Capitalism, which is immersed in mobility, multiplicity, lines escape, nomadism, material and social semiotic flows. Furthermore, in this logic, don't you work more with the idea of a "human being", but a "human" [9], which subscribes in the rhizome of life, in the infinity of thought, the micropolitical, in desires, in dematerialize the concreteness. The verb be finally gives way to the verb have and your fluidity.

According to Tavares, Irving and Vargas [9], "Liquid modernity can be con- 
sidered a background that psychosocial vectors agency" and, as such, the psychosocial look also contributes to reflect the continuous flow and constant of consumption from the logic of Rhizomatic Capitalism [15]. So, from the interface with psycho-sociology, how does the consumption process reveal contemporaneity?

\section{Consumer Society: From Being to Having}

In the contemporaneousness are perceived new factors that have changed significantly the consumption process under the aegis of the capital. It is observed that the technological development, the compulsion for high performance in the production, the consumer desires changed into requirements, creating consumer-facing trademark modeling, among other aspects, composed a new marketing diagram. The author Livia Barbosa, in your book entitled consumer society, questions about what would be the consumption under "label of consumer society" [18] and, according to her, the answer to that question depends on the theoretical approach used. Thus, the consumer society is one that can be defined by a specific type of consumption, the consumption of the sign or sign commodity such as Jean Baudrillard in your book the "consumer society". For others, would enclose sociological characteristics beyond commodity sign, as mass consumption and to the masses, consumerism and "disposal of goods per capita, presence of fashion, society, permanent feeling of disturbing insatiability and the consumer as one of its main social characters" [18].

This new logic, the Ephemerality and volatility of the processes emerge as rent-heads of the strategic processes of dissemination of new behaviors and ideas. The consumption reveals itself as the booster needs transformed into desires, in which the process of Exchange becomes feedback in favor of ephemerality and happiness tied to temporary Act of consuming. In this new order from the new textures created by Rhizomatic Capitalism, marked by the absence of limits and by the presence of constant modulations, the consumption becomes the propellant that insatiable desires satisfaction lever from the "have". Therefore, the consumption is now regulated by the market.

To understand how these new processes, in the context of Rhizomatic Capitalism, may influence or not on the creation of social business models, it is necessary to reveal the concepts that pervade the society of control through different looks, with the goal of introducing the necessary bases to find the reflection object of this research.

Guattari [19] understands consumer society as a society solidified by Integrated World Capitalism, showing a significant inclination to the subjective aspects that regulate social and consumer relations, affected by the logic of deterritorialization. In this way, the production of subjectivity [19] under the order of this new capitalist society, demonstrates itself to be decentralized, moving in different dimensions (social, political, environmental, economic, etc.) and producing behaviors that reinvent themselves continuously, to the new market demands. 
Featherstone [20] focuses on research of identities as being fragmented, hybrid and furniture. The offset or "decentering" of identity covers changes in contemporary times, where individuals are crossed by transformations in the field of identity that occur through conflicts and cultural, symbolic and social fragmentation. This movement gives rise to fragmentation or "pluralization" of identities.

Seen this, one can infer whether there is, in this process, a transformation of social business in trademark modeling that are soon consumed by the glow of a new buying opportunity, always more seductive than the previous one? Or even a form of resistance and activism in the logic of the consumer society?

\section{Social Business, Social and Environmental Impact: Some Clues}

The Social business offer several nomenclatures: social business, business with social impact, inclusive business, business impact, etc [5] and differ from NGOs and civil society organizations to use once seek financial sustainability, not depending on donations or other kind of support in this sense to stay. Also differ from the corporate social and environmental responsibility model as the "social impact is the driving force of the company, and not a positive externality or an action not tied to core business" [5].

The term social business arises from actions undertaken by Muhammad $\mathrm{Yu}$ nus, winner of the 2006 Nobel Peace Prize, which defines as "a venture designed to solve a social problem, must be self-sustaining, that is, generate enough income to cover its own costs" [21].

In terms of how they are in Brazil, businesses are organizations that may have several legal natures. Commercially, are the laws of supply and demand, define public, opportunities and risks, and using market mechanisms and marketing to achieve his purposes, selling products and services in various fields such as education, health, technology, etc.

That is, "The communication of the governments, in their different levels, or the communication of the companies, in the most different segments, cannot be separated from this reality" [6].

Moreover, it is observed that the new means of doing social marketing generate a compulsion in the consumers, who are attracted by the subjectivity of a Trademark modeling that is searched by social values of the good. That is, what changes for good or evil, are the ways in which marketing elaborates the processes of enunciation of the "Social Marketing", illustrated in Figure 2.

Thus, the motivation that makes a social business being born would not be the desire of profit itself, and the generation of social impact, social value [22]. Have, therefore, a motivation of financial and social return joint. It is not developed for personal gain, as in traditional business, but for the benefit of a group of people. According to SEBRAE definition:

The business of social impact positive social and environmental impact generated seek through the own enterprise's core business, i.e. the main 
activity must directly benefit people with lower income range, the classes $\mathrm{C}$, $\mathrm{D}$ and E, which According to the IBGE, in 2010, corresponding to $168 \mathrm{mil}-$ lion people. Therefore, economic viability and social and environmental concerns have the same importance and are part of the same business plan [23].

According to Wilson and Post [24], a social business must join the creation of social value and the creation of economic value in the same organizational structure. Social value should extend not only to the final consumer, but all stakeholders-customers, employees, suppliers, investors and society.

To Yunus, Moingeon, and Lehmann-Ortega [25], the social business must comply both with the social objectives both with operating costs, since it does not depend on donations. In the same logic, there should be withdrawal of dividends by shareholders/owners, being always surplus profits reinvested in the business.

When it comes to Social Affairs, automatically arises the concept of social impact. However, this term does not have a solid conceptual basis, with different points of view on the characteristics of the initiatives [26].

According to Petrini, Scherer and Back business with social impact are:

[...] organizations that aim to solve social problems-related demands, be offering products and services, is including individuals or groups. These organizations should promote your own financial sustainability, and optional profit sharing [22].

In this way, social impact would be the incorporation of social and environmental value in a sustainable way. Second Barki [5]:

The business impact, in its various terminologies, became a buzzword, or Buzzword. There are many organizations involved in this field and several universities in the world have discussed, researched and taught the business impact [5].

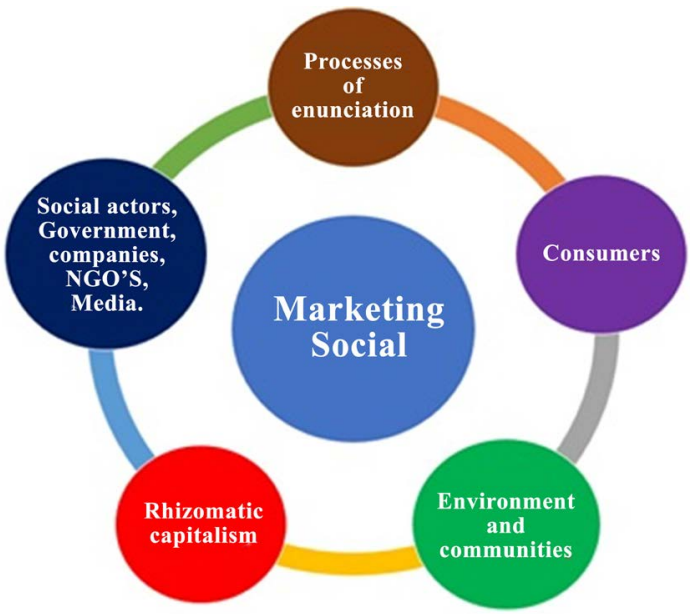

Figure 2. Diagram “Social Marketing Enunciation Processes”. Source: prepared by the authors, August 27, 2017. 
Barki [5] argues that there are two groups of actors in the process of creating social business: one of them would be composed of entrepreneurs who don't want to start a new business just as a way to get rich, but wish something else: make money and do good at the same time. And the other group, are young entrepreneurs who work in large companies, good quality of life and material goods that use alternatives to onerous and excessive work, but financial return as the main reward.

Thus, the Social business would be a response to latent desire of a part of the population that aspires to have your work effort involved in any social cause and/or environmental.

It's not simply a pressure of consumers more aware, but a force that comes

from the internal system of organizations, powered by a new generation of

entrepreneurs and employees more engaged in social causes [5].

Barki [5] States that the business impact may appear as an attempt to more inclusive capitalism and, more important than a clear and precise definition of what they are (or are not), it is necessary to recognize the trend that this hybrid form of organization represents. Thus, the next topic provides a methodology to analyze, from the study of Moradigna startup, the nuances, the logic of Rhizomatic Capitalism, which the social business can reflect about the expansion of capital for profit.

\section{Methodology}

To understand the process of deploying social business in contemporary times, with reference to a model developed in Brazil, this study followed the theoretical slopes covered by Deleuze, Guattari and others with such dialogue. From the construction of this theoretical framework, the methodology used to analyze the concepts in the case study is exploratory research made by means of a qualitative study. Were analyzed reports on Social business implemented in Brazil, with focus on Moradigna startup with the purpose of understanding the context studied from exploratory character study. The interpretation of the reports found was developed from precepts inspired by Content Analysis methodology [10].

With regard to the application of content Analysis according to inspiration in the precepts of Bardin [10], the author states that the intention is the inference of knowledge concerning production conditions (or, possibly, reception), that using indicators are They quantitative or not. "[...] the analyst takes advantage of the treatment of messages that handles, to inferred (deduced logically) knowledge of the sender of the message or about his environment, for example" [10].

Thus, the interpretation should be clearly related to the existing corpus, so that is validated by from the theoretical foundation built. The case study should therefore be systematized with the initial objectives, seeking the construction of scientific knowledge about the object searched, as can be seen below. 


\section{Social Business, Social Impact or Trademark Modeling? An Analysis of the Moradigna Startup}

The startup Moradigna, based on the outskirts of Sao Paulo, is self-appointed social business with the purpose of reforming unhealthy situation houses and settlement of land documents for affordable prices. It was created by Matheus Cardoso, engineer, with the objective of facing the problems that had already troubled him, since he grew up in a neighborhood with several problems of insalubrity.

Second article published in the Brazilian journal Época, as illustrated in Figure 3, the deal would have only the appearance of an NGO (non-governmental organization) in order to not collect money or make free services, as can also be viewed on statement made in Figure 4, on the site of one of its partners.

\section{Matheus Cardoso, 0 engenheiro que criou um Minecraft na vida real}

Ao fundar uma empresa que reforma casas e regulariza terrenos em bairros de baixa renda, ele criou um negócio que dá lucros e melhora a vida das pessoas

BRUNA MARTINS FONTES E RODRIGO TURRE

Figure 3. Site Report Época magazine. Source: Time Magazine online, 14 June 2016.

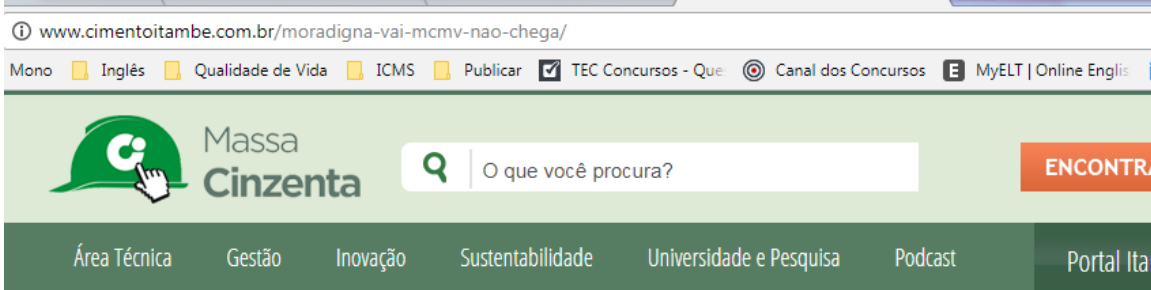

Home / Gestão/ Moradigna vai aonde Minha Casa Minha Vida não chega

Moradigna vai aonde Minha Casa Minha Vida não chega

13 de junho de 2017 Gestäo, Infraestrutura, Mercado da Construg̣âo Startup criada na Universidade Mackenzie se especializou em recuperar moradias insalubres na periferia da cidade de Săo Paulo

Por: Altalr Santos

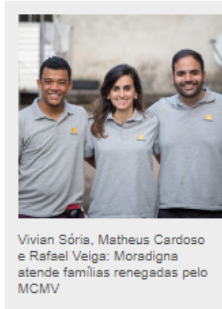

Uma startup criada dentro da Universidade Mackenzie, em 2015, foi o embrião para que o engenheiro civil Matheus Cardoso criasse a Moradigna. Ele juntou sua expertise à da arquiteta Vivian Sória e à do contabilista Rafael Veiga para apontar sua construtora na direção do empreendedorlsmo soclal. "Näa somos uma ONG (Organizaçẫo Não-Governamenta)), dizem, afirmando que o objetivo da empresa é somos uma ONG (Organizaciar

O campo de ação da Moradigna é a VIlla Pantanal, na região leste da cidade de São Paulo. Desde a criação da empresa, 220 famílias já foram atendidas. Atualmente, em média, são realizadas 25 reformas por mês. A maior demanda, explica Vivian Sória, está na recuperação de banheiros. "Eles são construidos sem nenhum revestimento, as paredes escurecem e o mofo costuma tomar conta do ambiente", afirma. Após as reformas as famílias beneficiadas dizem ter reduzido o número de doenças respiratórias, como gripe, resfriado, renite, bronquite e asma

Figure 4. Story company website Itambé Cements. Source: Blog site Itambé Cements, 13 June 2018. 


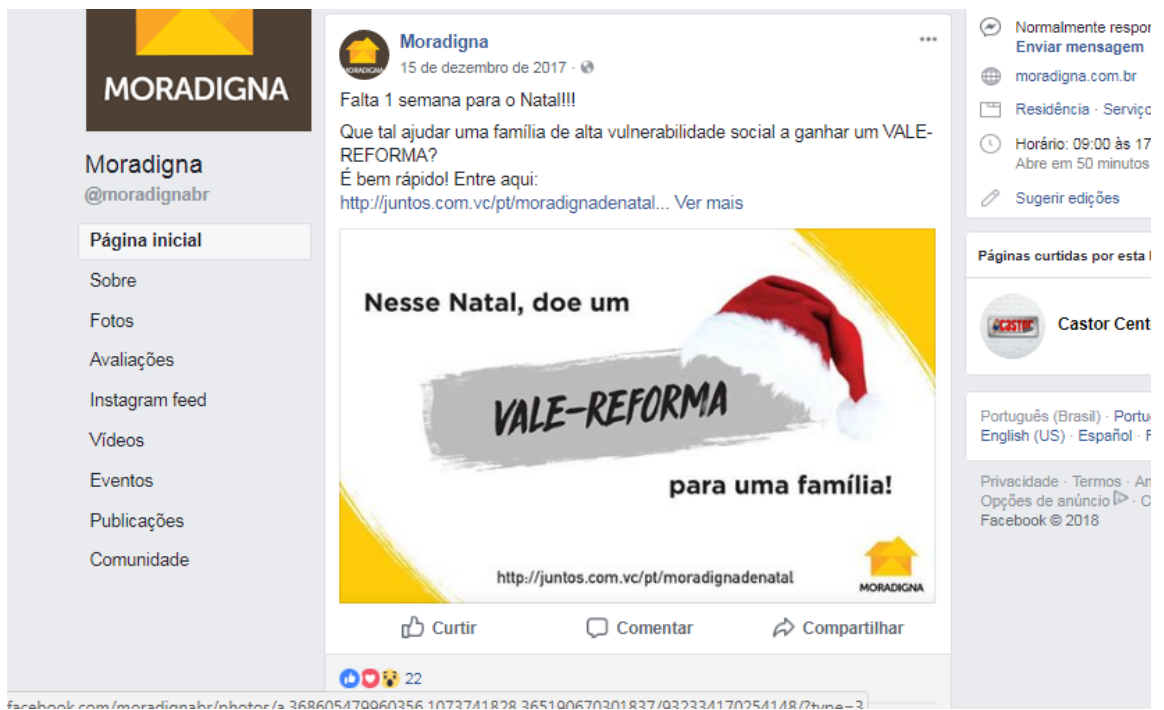

Figure 5. Posting the Moradigna on Facebook. Source: Moradigna Facebook Page, 17 December 2017.

Second statement by Matheus, the sale of the services work as boosting the impact in more and more families, the report in question. Thus, the Moradigna would be, according to your founder, a social business that pursues the profit to achieve benefits for the collective.

Despite these assertions about the Moradigna characteristics that define how social business startup promoted at the end of the year 2017 a campaign on your Facebook page (illustrated in Figure 5), which has approximately 7500 followers-to raise values to accomplish reforms, even business that purports to do only through sales, contrary to the scope of Social Affairs and the statement on article published in Época Magazine Online and on the blog of one of its partners. Under the logic of Rhizomatic Capitalism, can be inferred, from the application of the provisions of the content Analysis [10], the paradox observed in the case of Moradigna indicates the need of social business in if you repurpose, contrary to their own fundamentals, to adapt to the logic of the market, in need of expansion capital from new business strategies.

In another report published in the newspaper El Pais online (illustrated in Figure 6), the founder of Moradigna discusses on the aspect of cost reduction. According to the CEO of Moradigna, your big difference would be the fact of labor hired and paid on demand using people who live in their own neighborhood. Hiring "on demand" seems to indicate that the company-though to charge for the services and having profit margin "from 5\% and 10\%" (according to the website of the newspaper El Pais,), does not maintain employment bond with the people who perform the works out so possibly, the labor and social security guarantees of these individuals in the community.

Conversely, Matthew affirms that this process creates an "empowerment" for the community, generating income for these workers in order to retain the "wealth" within the Community. Here one can observe the presence of the matter 


\section{$\equiv$ EL PAISS}

EMPREENDEDORISMO ,

\section{0 engenheiro que quer transformar a periferia onde cresceu}

Matheus Cardoso, morador do Jardim Pantanal, na zona leste de SP, fundou o Moradigna. Empresa que reforma casas em condições insalubres na região em que vive

\section{0 (5)}

Figure 6. Story Newspaper El Pais. Source: El Pais online, August 232017.

of immateriality and the fluidity [15], to the extent that the social business, under the logic of Rhizomatic Capitalism, acts in the sphere of new subjectivities and trademark modeling that sustain the cycle of consumption entangled by desire transmuted into needs.

At the same time, the Moradigna reflects a social business with a tendency to unite social value creation and the creation of economic value in the same organizational structure in the affirmation of Matheus, still in the story of El Pais, which is less costly to have employees who live in the community itself, because you don't have to pay shipping. From the analysis of some points of these reports, this article weaves some concerns.

\section{Final Considerations}

By contrasting the two possibilities, both as a model of social impact and as trademark modeling, the possibility of social business becomes a tool of Rhizomatic Capitalism in the perspective of the consumer society. This move turns out to be the result of a multiplicity of factors that motivate many entrepreneurs to seek new ways of interacting with the market. However, it is observed that this business practice can not only be tied to motivations surrounding the need for social impact. Through this vision, it is observed that the creation of social business can bring, in a way, a hybridism of intent. This does not occur only when the brand modeling translate into market trends, but also reflect entrepreneurs anxious to act ethically and sustainably, indicating, however, still a shy way of expressing a form of "improve the world", it would be at first the objective end of the creation of this business model.

It could be inferred, through this study, that the entrepreneur Social Business outlines the need to belong to a group that supports a behavior of "social entrepreneurship". On the other hand, the capitalist culture associated with these new "ways of being", in the context of the consumer society, culminating in the multiplication of social trademark modeling that reproduce the characteristics inherent to the resignification of Rhizomatic Capitalism.

The way in which marketing appropriates processes of enunciation to capture the consumers of less favored social classes can be understood as a "social trademark modeling", for it is resistance that creates adherence. 
In view of the theoretical here built trailer to the documentary and bibliographical research, one cannot say that the social business movement consolidated, at that time, as a way of business model with solid social impact. This is because the analytical axes that resulted from this theoretical clipping indicate that relations between the speech "social entrepreneurship" and the setting as trademark modeling may suffer influences and changes constantly according to the dictates of market and consumption for capital expansion.

Thus, it is suggested as future research, an analysis of the context of social marketing in relation to the dynamics of the transformation of the social business model.

\section{Conflicts of Interest}

The authors declare no conflicts of interest regarding the publication of this paper.

\section{References}

[1] Cazzali, A.R. (2006) Comunicação e Meio Ambiente no Fortalecimento da Marca. Dissertação (Mestrado em Comunicação Social) Universidade Metodista de São Paulo, São Paulo.

[2] Comini, G. and Teodósio, A. (2012) Responsabilidade social empresarial no combate a pobreza: Perspectivas e desafios dos Negócios Inclusivos no contexto brasileiro. In: Encontro Nacional de Pesquisadores em Gestão Social (ENAPEGS), 6., São Paulo, 21-23 maio 2012, ENAPEGS, São Paulo.

[3] Iizuka, E.S., et al. (2014) Empreendedorismo Social e Negócios Sociais: Revisão Crítica e Agenda de Pesquisa. SEMEAD FEA-USP.

[4] Ferreira, G. and Tavares, F. (2017) Natureza Líquida: As modelagens marcárias e a publicidade verde. Editora Appris, Rio de Janeiro, 28.

[5] Barki, E. (2015) Negócios de impacto: Tendência ou modismo? GVexecutivo, 14, 14-17. https://doi.org/10.12660/gvexec.v14n1.2015.49183

[6] Almeida, F. (2012) Desenvolvimento Sustentável 2012-2050. Visão, Rumos e Contradições. Elsevier, Rio de Janeiro, 42-66.

[7] Freeman, R.E. (1984) Strategic Management: A Stakeholder Approach. Boston: Pitman. Cambridge University Press, New Yok.

[8] ARTEMISIA. (2018). https://artemisia.org.br/conteudo/frentes/aceleradora/o-programa/o-programa

[9] Tavares, F., Irving, M. and Vargas, R. (2014) O “Ter Humano" e os "Kits de Subjetividade": Uma Perspectiva Psicossociológica do Consumo Através da Publicidade. In: Intercom-Sociedade Brasileira de Estudos Interdisciplinares da Comunicação-XXXVI Congresso Brasileiro de Ciências da Comunicação, Manaus, 3.

[10] Bardin, L. (1977) Análise de Conteúdo. Edições 70, Lisboa, 39.

[11] Guattari, F. and Rolnik, S. (2005) Micropolítica: Cartografias do desejo. Editora Vozes, Petrópolis.

[12] Sibilia, P. (2003) O homem pós-orgânico: corpo, subjetividade e tecnologias digitais. Relume Dumará, Rio de Janeiro.

[13] Alliez, É. (2000) Gilles Deleuze: Uma vida filosófica. Editora 34, São Paulo. 
[14] Guattari, F. (1987) Revolução Molecular: Pulsações Políticas do Desejo. Brasiliense, São Paulo.

[15] Pelbart, P.P. (2003) Vida capital: Ensaios de biopolítica. Iluminuras 96, São Paulo.

[16] Camargo, A.C. (2011) Félix Guattari: O capitalismo mundial integrado. VII Seminário de Pós-Graduação em Filosofia da UFSCar Anais, São Carlos, 69-71.

[17] Sibilia, P. (2008) O show do eu: A intimidade como espetáculo. Nova Fronteira, Rio de Janeiro.

[18] Barbosa, L. (2004) Sociedade de consumo. Zahar, Rio de Janeiro, 8-18.

[19] Guattari, F. (1990) As três ecologias. Trad. Maria Cristina F. Bittencourt. Papirus, São Paulo.

[20] Featherstone, M. (1995) Cultura de consumo e pós-modernismo. Studio Nobel, São Paulo.

[21] Yunus, M. (2010) Criando um Negócio Social: Como iniciativas economicamente viáveis podem solucionar os grandes problemas da sociedade. Elsevier, Rio de Janeiro.

[22] Petrini, M., Scherer, P. and Back, L. (2016) Modelo de negócio com impacto social. RAE Revista de Administração de Empresas, 56, 209-225. https://doi.org/10.1590/S0034-759020160207

[23] Sebrae. Negócios de Impacto Social. http://www.negociosdeimpactosebrae.com.br/projeto

[24] Oliveira, et al. (2016) Negócios sociais como estratégia para solucionar problemas globais. 26 Conferência Anprotec de Empreendedorismo e Ambientes de Inovação.

[25] Yunus, M., Moingeon, B. and Lehmann-Ortega, L. (2010) Building Social Business Models: Lessons from the Grameen Experience. Long Range Planning, 43, 308-325. https://doi.org/10.1016/j.lrp.2009.12.005

[26] Rosolen, T., Tiscoski, G.P. and Comini, G.M. (2015) Empreendedorismo social e negócios sociais: Um estudo bibliométrico da publicação nacional e internacional. In: Santana, A.L.J., De, M. and de Souza, L.M., Eds., Empreendedorismo com Foco em Negócios Sociais, NITS UFPR, Curitiba, 140-163. 